\title{
MENINGKATKAN HASIL BELAJAR MATEMATIKA MELALUI MODEL PEMBELAJARAN KOOPERATIF JIGSAW
}

\author{
Rosita Aritonang \\ e-mail: astuti_fuji22@yahoo.com \\ SDN Duri Pulo 01 Pagi
}

\begin{abstract}
Abstrak: Penelitian ini dilaksanakan Februari sampai dengan April 2013 di SDN Duri Pulo 01 Pagi, Semester 1 Tahun Pelajaran 2013/2014. Subjek penelitian ini adalah kelas VI SD. Penelitian tindakan kelas dengan model pembelajaran kooperatif Jigsaw ini bertujuan meningkatkan mutu pembelajaran matematika. Hasil penelitian tindakan kelas ini menunjukkan peningkatan hasil belajar siswa pada pembelajaran Matematika. Setelah melalui dua siklus, terdapat kenaikan hasil belajar siswa secara bermakna sehingga disimpulkan seluruh komponen aktivitas siswa dalam pembelajaran mengalami kenaikan. Berdasarkan hasil belajar dan aktivitas siswa, dapat disimpulkan, model pembelajaran kooperatif Jigsaw dapat meningkatkan hasil belajar Matematika pada kompetensi dasar bilangan bulat pada siswa kelas VI SDN Duri Pulo 01 Pagi Jakarta Pusat.
\end{abstract}

Kata kunci: hasil belajar, model pembelajaran kooperatif, model Jigsaw.

\section{IMPROVING LEARNING ACHIEVEMENT IN MATHEMATICS THROUGH JIGSAW COOPERATIVE INSTRUCTIONAL MODEL.}

\begin{abstract}
This classroom action research was conducted as from February through April 2013 at Government Primary School 1, Semester 1, School Year of 2013/2014. The research subjects are the students of Grade VI. The purpose of the research was to improve the teaching-learning process in Mathematics. After 2 cycles, the students' learning achievement significantly improved. Based on the students' learning activities and achievement, it was concluded, the cooperative instructional model Jigsaw can be used to improve the student's achievement in Mathematics particularly in the topic of even numbers in Grade VI, Primary School.
\end{abstract}

Keywords: learning achievement, cooperative instructional model, jigsaw model.

\section{PENDAHULUAN}

Akibat salah menggunakan teknologi canggih atau internet terutama lingkungan hidup siswa maka minat belajar siswa SDN DURI PULO 01 Pagi sangat kurang efektif. Belajar merupakan proses perubahan tingkah laku individu yang relatif tetap sebagai hasil dari pengalaman. Sedangkan pembelajaran merupakan upaya penataan lingkungan yang memberi nuansa agar program belajar tumbuh dan berkembang secara optimal. Menurut konsep sosiologi, belajar adalah jantungnya dari proses sosialisasi dan pembelajaran adalah rekayasa sosio-psikologis untuk memelihara kegiatan belajar tersebut sehingga setiap individu akan belajar secara optimal dalam mecapai tingkat kedewasaan dan dapat hidup sebagai anggota masyarakat yang baik.

Kegiatan pembelajaran pada dasarnya merupakan kegiatan yang melibatkan antar beberapa komponen pembelajaran.Di antara komponen pembelajaran yang terlibat adalah siswa dan guru.
Interaksi yang dibangun dalam kegiatan ini adalah interaksi yang bersifat dua arah dan menempatkan siswa bukan sebagai objek belajar tetapi sebagai subjek belajar.

Kedudukan siswa sebagai subjek belajar berarti siswa merupakan individu yang aktif, bukan yang pasif, yang hanya menerima apa yang diberikan oleh guru. Dalam model pembelajaran Cooperative learning Tipe Jigsaw, siswa dituntut untuk banyak melakukan aktifitas sesuai dengan tema yang dikembangkan dalam materi pembelajaran. Siswa dituntut untuk menemukan konsep-konsep penting yang dikembangkan dalam tema materi pembelajaran atau melakukan inquiri. Guru hanya berperan sebagai fasilisator untuk mengantarkan siswa hingga menemukan konsep-konsep tersebut.

Proses inquiri yang dilakukan oleh siswa harus didukung oleh media dan sumber belajar yang digunakan oleh guru. Media dan sumber belajar tidak hanya terpaku pada buku teks yang dijadikan pegangan oleh guru.Apabila hal ini 
dilakukan informasi materi pembelajaran sangat terbatas. Hal yang ideal adalah media dan sumber belajar harus memberikan kemudahan bagi siswa dalam memperoleh materi yang nantinya dapat dikembangkan dalam tema pembelajaran.Salah satu media dan sumber materi yang bisa dikembangkan adalah melalui Teknologi Informasi dan Komunikasi (TIK).

Dengan berdasarkan pada uraian latar belakang di atas, pada bagian ini penulis mengidentifikasi area dan fokus penelitian sebagai berikut: (1) bagaimanakah hasil belajar matematika pada kompetensi dasar bilangan penjumlahan dan pengurangan tiga angka siswa kelas VI SDN Duri Pulo 01 Pagi Jakarta?; (2) bagaimanakah meningkatkan hasil belajar matematika Siswa Kelas VI SDN Duri Pulo 01 Pagi Jakarta?; (3) bagaimanakah pemahaman siswa terhadap mata pelajaran matematika pada kompetensi dasar bilangan penjumlahan dan pengurangan bilangan tiga angka siswa kelas VI SDN Duri Pulo 01 Pagi Jakarta?; (4) apakah guru di SDN Duri Pulo 01 Pagi Jakarta menggunakan model Cooperative learning Tipe Jjigsaw?; (5) apakah model Cooperative learning Tipe Jigsaw dapat meningkatkan hasil belajar siswa di SDN Duri Pulo 01 Pagi Jakarta?.

Berdasarkan latar belakang dan identifikasi masalah di atas, maka perumusan masalah adalah sebagai berikut: "Bagaimana model pembelajaran cooperative learning tipe jigsaw dapat meningkatkan hasil belajar matematika pada kompetensi dasar bilangan bulat pada siswa kelas VI SDN Duri Pulo 01 Pagi Jakarta Pusat Semester Ganjil Tahun 2013/2014?"

Tujuan dalam penelitian ini yaitu: (1) menerapkan model cooperative learning tipe jigsaw dalam pembelajaran Matematika dan (2) mengetahui kebermanfaatan model cooperative learning tipe jigsaw dalam meningkatkan hasil belajar siswa khususnya mata pelajaran Matematika.

Manfaat dalam penelitian ini yaitu: (1) untuk siswa, meningkatkan hasil belajar pada mata pelajaran Matematika, meningkatkan kompetensi siswa pada kompetensi dasar bilangan bulat, merubah paradigma siswa terhadap mata pelajaran matematika; (2) untuk guru, menerapkan model cooperative learning tipe jigsaw, menemukan model pembelajaran yang tepat untuk mata pelajaran matematika di kelas VI SDN Duri Pulo 01 Pagi Jakarta Pusat; (3) untuk sekolah, sebagai informasi untuk mengenal keberadaan anak didiknya sehingga dapat mengambil langkah tepat dalam membimbing dan mengarahkan anak meraih hasil belajar yang baik.

Menurut Syaifudin Azwar (2001 : 164), “'belajar adalah setiap perubahan perilaku yang diakibatkan pengalaman atau sebagai hasil interaksi individu dengan lingkungannya". Pendapat ini mempertegas bahwa manusia bersifat dinamika dan terbuka terhadap berbagai bentuk perubahan yang dapat terjadi pada dirinya dan pada lingkungan sekitarnya, maka proses belajar akan selalu tejadi tanpa dalam kehidupan manusia.

Surakhmad (1979: 78) menyatakan, “belajar pada hakekatnya adalah kegiatan yang dilakukan oleh seseorang secara sadar sehingga menghasilkan suatu perubahan tingkah laku pada diri si pelajar (orang yang belajar) itu sendiri". Pendapat ini mempertegas bahwa belajar itu merupakan suatu perubahan dalam bentuk sikap dan nilai positif. Selama kegiatan belajar berlangsung terjadi proses interaksi antara si pelajar dengan sumber-sumber belajar.

Kesimpulannya, bahwa belajar adalah tindakan yang dilakukan individu dalam keadaan sadar dan tanpa ada paksaan darimana pun dan juga merupakan suatu perubahan perilaku yang merubah perilaku seseroang untuk menjadi yang lebih baik lagi untuk diri nya sendiri.

Hasil belajar adalah "hasil yang telah dicapai dari yang telah dilakukan ketika belajar" (Sri Esti Wuryani: 2006, 361). Sebagai siswa yang mulai belajar di kelas, mereka membawa sikap dan kebutuhan yang berbeda-beda.Keduanya, sikap dan kebutuhan mempengaruhi prestasi dan partisipasi di dalamnya.Selama pelajaran, terlihat segela kegiatan siswa, perasaan-perasaannya dan pengalamanpengalamannya mempengaruhi motivasi..

Dalam teori taksonomi, tujuan pendidikan yang dikemukakan oleh Benjamin S. Bloom adalah "tujuan ranah kognitif, afektif, dan psikomotor" (Bloom : 1956). Untuk mendapatkan suatu hasil belajar yang baik tidaklah semudah yang dibayangkan, karena memerlukan perjuangan dan pengorbanan dengan berbagai tantangan yang harus dihadapi. Penilaian terhadap hasil belajar siswa untuk mengetahui seberapa jauh ia telah mencapai sasaran belajar inilah yang disebut sebagai hasil belajarpemahaman, dalam bidang pengalaman eduktif berupa perubahanperubahan pola tingkah laku tersebut diorganisir untuk mencapai prestasi belajar berdasarkan tujuan pembelajaran yang diharapkan

Proses pembelajaran matematika yang disediakan di sekolah telah diusahakan berjalan seoptimal mungkin dengan mengikuti rambu-rambu yang telah ditentukan dalam kurikulum. Setiap pelajaran yang ditentukan dalam struktur kurikulum memiliki standar kompetensi yang harus dicapai oleh 
siswa. Standar kompetensi pelajaran matematika adalah sebagai berikut: a) memahami konsep bilangan bulat dan pecahan, operasi hitung dan sifatsifatnya. b) Memahami bangun datar dan bangun ruang sederhana, unsur-unsur dan sifat-sifatnya. c) Memahami konsep koordinat untuk menentukan letak benda dan menggunakannya.d) Memahami konsep ukuran dan pengukuran berat, panjang, luas, volume, sudut, waktu, kecepatan, debit, serta mengaplikasikannya .

James dan James dalam Ruseffendi, 1984 : 27) menyatakan "matematika adalah ilmu tentang logika mengenai bentuk, susunan, besaran, dan konsepkonsep yang saling berhubungan satu sama lainnya dengan jumlah yang banyaknya terbagi ke dalam tiga bidang, yaitu aljabar, analisis dan geometri.

Matematika adalah "pola berpikir, pola mengorganisasikan pembuktian yang logis". Kemudia Reys menyatakan matematika adalah "telaahan tentang pola dan hubungan, suatu jalan atau pola berpikir, suatu seni, suatu bahasa dan suatu alat".

Berdasarkan beberapa kutipan pendapat di atas maka matematika adalah ilmu deduktif yang tidak menerima generalisasi yang didasarkan kepada pengamatan atau observasi (induktif) tetapi generalisasi itu harus didasarkan kepada pembuktian secara deduktif.

Salah satu aspek yang mendukung guru merumuskan bentuk pembelajaran yang cocok untuk seluruh siswa di kelas adalah dengan pemilihan dan penggunaan metode pembelajaran yang tepat. Yang dimaksud dengan metode adalah "cara yang teratur dan terpikir baik-baik untuk mencapai maksud atau tujuan, cara kerja yang bersistem untuk memudahkan pelaksanaan suatu kegiatan guna mencapai tujuan yang ditentukan (Mulyono 1995: 65).

Metode pembelajaran adalah cara-cara atau teknik penyajian bahan pelajaran yang akan digunakan oleh guru pada saat menyajikan bahan pelajaran baik secara individual maupun secara kelompok menurut ( sabri 2007: 49)

Model pembelajaran, pengajar merupakan salah satu komponen pengajaran yang harus diperhatikan oleh guru pemilihan metode yang tepat dalam proses belajar mengajar dapat membantu siswa untuk mencapai tujuan pembelajaran dengan efktif dan efisien.

Dalam menentukan metode yang digunakan perlu diperhatikan hal-hal sebagai berikut: (1) keinginan anak yang berbeda-beda yang disebabkan adanya perbedaan dalam bakat dan minat anak, teori belajar yang digunakan serta media yang digunakan;
(2) jumlah murid yang hendak diajar; (3) tempat penggunaan metode mengajar (Dendasurono 1988 : 29).

Berbagai aktifitas belajar dapat dilakukan oleh guru, baik belajar sendiri maupun belajar yang dilakukan secara bersama-sama atau yang dikenal dengan belajar kelompok. Kegiatan belajar kooperatif biasanya dilakukan ketika guru memberikan tugas yang harus diselesaikan secara berkelompok/ bekerja sama. Akan tetapi, ada pula kegiatan belajar kelompok yang bertujuan untuk mendalami pelajaran yang telah diterima di sekolah secara bersama-sama dengan teman sebaya. Kegiatan kooperatif lebih sering dilakukan ketika siswa mengerjakan tugas kelompok yang diberikan oleh guru.

Langkah-langkah tipe Jigsaw: pertama, guru membagi satu kelas menjadi beberapa kelompok dengan setiap kelompok terdiri dari 4 - 6 siswa dengan kemampuan berbeda. Kelompok ini disebut kelompok asal. Jumlah anggota dalam kelompok asal menyesuaikan dengan jumlah bagian materi pelajaran yang akan dipelajari siswa dengan tujuan pembelajaran yang akan dicapai. Setiap siswa diberi tugas mempelajari salah satu bagian materi pembelajaran tersebut semua siswa dengan materi yang sama dalam kelompok yang disebut kelompok ahli. Dalam kelompok ahli, siswa mendiskusikan bagian materi pembelajaran yang sama, serta menyusun rencana bagaimana menyampaikan kepada temannya jika kembali ke kelompok asal, kelompok asal oleh Aronson disebut jigsaw (gigi gergaji). Misalnya 1 kelas dengan jumlah 40 siswa dan materi pembelajaran yang akan dicapai sesuai tujuan pembelajaran terdiri dari 5 bagian materi pembelajaran, maka dari 40 siswa akan terdapat 5 kelompok ahli yang beranggotakan 8 siswa dan 8 kelompok asal yang terdiri dari 5 siswa. Setiap anggota kelompok ahli akan kembali kekelompok asal memberikan informasi yang telah diperoleh atau dipelajari oleh kelompok ahli.

Kedua, setelah siswa berdiskusi dalam kelompok ahli maupun kelompok asal, selanjutnya dilakukan presentasi masing-masing kelompok atau dilakukan perundingan salah satu kelompok untuk menyajikan hasil diskusi kelompok yang telah dilakukan agar guru dapat menyamakan persepsi pada materi pembelajaran yang telah didiskusikan. Ketiga, guru memberikan kuis untuk siswa secara individual. Sera keempat, guru memberikan pengarahan pada kelompok melalui skor penghargaan berdasarkan perolehan nilai peningkatan hasil belajar individual dari skor dasar ke kuis berikutnya.

Konsep kaji tindak atau action research awalnya 
muncul dalam hanya seorang ahli psikologi Social Kurt Lewin (1996) yang mengembangkan dan menerapkan selama bertahun-tahun.Dia mendeksripsikan action research sebagai langkah dalam bentuk spiral yang terdiri dari perencanaan (planning), tindakan (action) dan evaluasi hasil tindakan (action).Tiga langkah dalam spiral ini (siklus yang berulang-ulang) merupakan ciri khas utama penelitian tindakan sampai sekarang.

Penelitian tindakan kelas merupakan suatu bentuk investigasi yang bersifat partisipatif, kolaboratif dan spiral yang memiliki tujuan untuk memperbaiki sistem, metode kerja, proses isi, kompetensi dan situasi (Arikunto Suharsimi, dkk, 2006:104).

Penelitian Tindakan Kelas (PTK) biasa dikenal dengan classroom action research adalah sebuah penelitian yang dilakukan oleh guru di kelasnya sendiri dengan jalan merancang, melaksanakan dan merefleksikan tindakan secara kolaboratif dan partisipatif (Suhardjono, 2009:8).

Ciri khas dalam PTK adalah adanya tindakan yang dilakukan berulang-ulang (siklus) dalam rangka mencapai perbaikan yang diinginkan. Penelitian Tindakan Kelas dilaksanakan berupa proses pengkajian berdaur (siklus) yang terdiri dari 4 tahap yaitu: 1 Merencanakan, 2. Melakukan tindakan, 3. Mengamati dan 4. Refleksi.

Dalam penelitian kaji tindak siklus merupakan ciri khas yang membedakannya dari penelitian jenis lain, karena siklus harus dilaksanakan dengan benar. Siklus yang dilakukan meliputi perencanaan, tindakan, pengamatan yang sistematik terhadap tindakan, refleksi dan perencanaan kembali dan demikian seterusnya.Berikut skema pelaksanaan siklus dalam penelitian kaji tindak sebagai gambaran prosedur penelitian. Suwandi, dan Sawiji (2010 : 12)

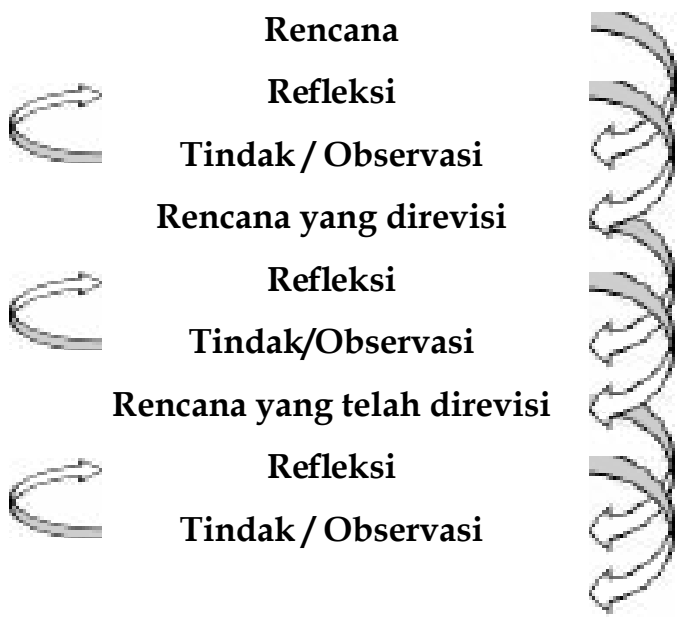

Gambar 1. Spiral penelitian tindakan kelas

Gambar di atas memperlihatkan kaji tindak siklus terdiri dari: (1) perencanaan, (2) pelaksanaan,
(3) pengamatan, (4) refleksi, yang kemudian diikuti dengan perencanaan kembali untuk siklus berikutnya, bila hasilnya baik.

Salah satu aspek yang dicapai pada saat belajar adalah hasil belajar. Hasil belajar merupakan sesuatu yang dicapai siswa setelah mengikuti proses belajar mengajar di kelas maupun di sekolah. Hasil belajar dapat berupa laporan hasil ulangan mid-semester dan ulangan semester. Hasil belajar siswa dapat diketahui setelah diadakan penilaian atau evaluasi.

Melaksanakan pembelajaran di sekolah memerlukan banyak faktor, salah satunya dalah metode. Metode merupakan suatu cara atau teknik yang dilakukan untuk menyampaikan materi pelajaran kepada siswa. Model pembelajaran cooperative learning tipe jigsaw merupakan metode pembelajaran yang melibatkan siswa dalam sebuah kelompok.Melalui metode cooperative learning tipe jigsaw siswa dilatih untuk mandiri sehingga memperoleh pemahaman yang lebih baik.

Berdasarkan uraian diatas maka hipotesis tindakan yang dirumuskan dalam penelitian ini adalah : "Model pembelajaran cooperative learning tipe jigsaw dapat meningkatkan hasil belajar Matematika pada kompetensi dasar bilangan bulat pada siswa kelas VI SDN Duri Pulo 01 Pagi Jakarta Pusat Semester Ganjil Tahun 2013/2014.

\section{METODE PENELITIAN}

Penelitian Tindakan Kelas ini dilaksanakan di kelas VI SDN Duri Pulo 01 Pagi - Kecamatan Gambir - Jakarta Pusat pada semester Ganjil Tahun Pelajaran 2013/2014 selama 4 bulan mulai bulan September sampai dengan November 2013. Subjek penelitian tindakan kelas adalah peserta didik kelas VI SDN Duri Pulo 01 Pagi Jakarta Pusat Tahun Pelajaran 2013/2014 Semester ganjil berjumlah 38 siswa dengan perincian jumlah siswa laki-laki 21 orang dan siswa perempuan 19 orang. Dengan alasan bahwa kelas yang menjadi sampel dalam penelitian ini karena memiliki karakteristik yang berbeda dibandingkan kelas di bawahnya, juga karena peneliti sebagai wali kelas VI di sekolah.

Metode penelitian yang digunakan dalam penelitian ini adalah Metode Penelitian Tindakan Kelas (PTK). Penelitian Tindakan Kelas (PTK). Adalah tindakan untuk memperbaiki mutu praktik pembelajaran di kelasnya sehingga berfokus proses belajar mengajar yang terjadi di kelas. PTK ini adalah tindakan yang nyata yang langsung dilakukan oleh guru dalam pembelajaran di kelas, yang dinyatakan lebih baik daripada yang biasa dilakukan. (sihardjono, 
$2011: 9)$

PTK digambarkan sebagai proses yang dinamis meliputi aspek perencanaan, tindakan observasi dan refleksi yang merupakan langkah berurutan dalam satu siklus yang berhubungan dengan siklus berikutnya. Alur pelaksanaan PTK digambarkan 2.

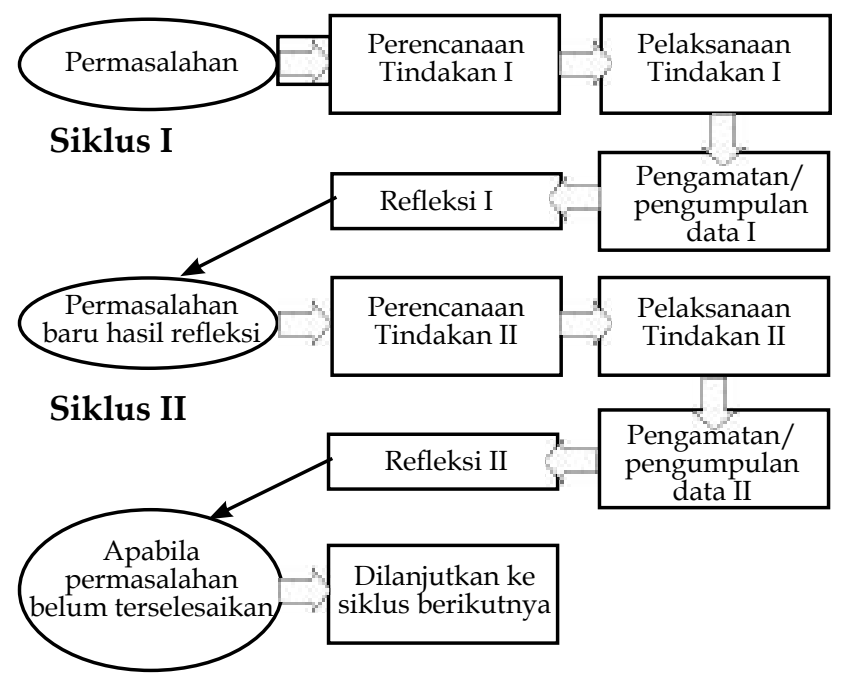

Gambar 2. Model alur pelaksanaan tindakan kelas dalam PTK model Hopkins

\section{Siklus I}

\section{Pertemuan I (Selasa, 1 September 2013)}

(Waktu : 2 jam pelajaran $=2 \times 35$ menit)

a. Perencanaan: (1) menyusun silabus pembelajaran sesuai dengan kompetensi dasar mata pelajaran matematika tentang bilangan bulat, (2) menyusun rencana pelaksanaan pembelajaran (RPP) matematika sesuai dengan kompetensi dasar dan silabus, (3) menyusun tes awal untuk mengetahui hasil belajar siswa, (4) menentukan lembar observasi / pengamatan, dan (5) menyusun angket persepsi siswa untuk maple matematika.

b. Pelaksanaan: (1) melaksanakan proses pembelajaran berdasarkan rencana yang telah disusun dan telah ditentukan, (2) menyiapakan siswa dalam kelas dan berdoa sebelum pelajaran di mulai, (3) memberikan tes awal, (4) menyusun kelompok siswa menjadi beberapa kelompok dan menentukan kelompok ahli, (5) memberikan penjelasan kepada siswa tentang materi pelajaran, (6) menyampaikan materi bilangan bulat tiga angka, dan (7) memberikan tes kepada siswa untuk mengukur keberhasilan pembelajaran

c. Pengamatan

Kegiatan yang dilakukan adalah observer mengamati pelaksanaan pembelajaran dengan menggunakan lembar pengamatan/observasi. Observasi ini dilakukan untuk mengetahui kesesuaian pelaksanaan tindakan dengan rencana tindakan yang telah disusun sebelumnya, serta untuk mengetahui seberapa jauh pelaksanaan tindakan yang sedang berlangsung dapat menghasilkan perubahan yang diharapkan yaitu meningkatkan hasil belajar Matematika.

\section{d. Refleksi}

Hasil observasi setelah pelaksanaan tindakan dievaluasi bersama kolaborator dengan mengadakan diskusi evaluasi dan meninjau masalah.Kemudian hasil evaluasi dan refleksi didiskusikan kembali dengan kolaborator dan hasil kesepakatan disampaikan kepada kepala sekolah untuk dijadikan dasar pembuatan perencanaan siklus berikutnya.

\section{Pertemuan 2 (Kamis, 03 Oktober 2013)}

(Waktu 2 Jam Pelajaran $=2 \times 35$ menit)

a. Perencanaan: (1) menyusun silabus pembelajaran sesuai dengan kompetensi dasar mata pelajaran matematika tentang bilangan bulat lanjutan pertemuan pertama dengan metode Jigsaw dan (2) menyusun rencana pelaksanaan pembelajaran (RPP) matematika sesuai dengan kompetensi dasar dan silabus.

b. Pelaksanaan: (1) melaksanakan proses pembelajaran berdasarkan rencana yang telah disusun dan telah ditentukan, lanjutan dari pertemuan pertama; (2) memberikan penjelasan kepada siswa tentang materi pelajaran yang akan diberikan yaitu bilangan bulat; (3) memberikan contoh bilangan bulat positif dan negatip; (4) mengajukan pertanyaan kepada siswa tentang materi pelajaran yang disampaikan; (5) mengamati perilaku, siswa selama pembelajaran berlangsung dengan bantuan observer.

c. Pengamatan

Proses pengamatan pembelajaran dilakukan oleh kolaborator. Kolaborator adalah teman sejawat yang mengamati saat pelaksanaan kegiatan berlangsung.Kegiatan yang dilakukan adalah observer mengamati pelaksanaan pembelajaran dengan menggunakan lembar pengamatan/observasi. Observasi ini dilakukan untuk mengetahui kesesuaian pelaksanaan tindakan dengan rencana tindakan yang telah disusun sebelumnya, serta untuk mengetahui seberapa jauh pelaksanaan tindakan yang sedang berlangsung dapat menghasilkan perubahan yang diharapkan.

d. Refleksi

Berdasarkan hasil analisis data, peneliti bersama dengan kolaborator melakukan refleksi untuk mengadakan diskusi, evaluasi dan meninjau masalah. Kemudia hasil evaluasi dan refleksi didiskusikan kepada kepala sekolah untuk dijadikan sebagai dasar pembuatan perencanaan siklus berikutnya. 


\section{Pertemuan 3 (Selasa, 08 Oktober 2013)}

(Waktu : 2 Jam pelajaran $=2 \times 35$ menit)

a. Perencanaan: (1) menyusun instrument tes untuk mengetahui hasil belajar yang dicapai selama siklus I. sesuai dengan kompetensi dasar yang di ajarkan yaitu bilangan bulat; (2) membuat lembar observasi/pengamatan.

b. Pelaksanaan: (1) melaksanakan kegiatan tes berdasarkan rencana yang telah disusun dan telah ditentukan; (2) mengamati dan mengawasi kegiatan tes bersama observer; (3) mencatat kegiatan siswa selama tes berlangsung; (4) mengoreksi hasil belajar siswa apakah sudah ada perbaikan atau belum.

c. Pengamatan

Proses pengamatan pembelajaran dilakukan oleh kolaborator. Kolaborator adalah teman sejawat yang mengamati saat pelaksanaan kegiatan berlangsung. Kegiatan yang dilakukan adalah observer mengamati pelaksanaan tes dengan menggunakan lembar pengamatan/observasi.Observasi ini dilakukan untuk mengetahui kesesuaian pelaksanaan tindakan dengan rencana tindakan yang telah disusun sebelumnya, serta untuk mengetahui seberapa jauh pelaksanaan tindakan yang sedang berlangsung dapat menghasilkan perubahan yang diharapkan.

d. Refleksi

Berdasarkan hasil analisis data, peneliti bersama dengan kolaborator melakukan refleksi untuk mengadakan diskusi, evaluasi dan meninjau masalah. Kemudian hasil evaluasi dan refleksi didiskusikan kembali dengan kolaborator dan hasil kesepakatan disampaikan kepada kepala sekolah untuk dijadikan sebagai dasar pembuatan perencanaan siklus berikutnya.

\section{Siklus II}

\section{Pertemuan 1 (kamis, 10 Oktober 2013)}

Waktu : 2 Jam pelajaran $=2 \times 35$ menit

a. Perencanaan

Dari hasil refleksi data yang akan diperoleh dari observer pada siklus I, peneliti menyusun rencana untuk pelaksanaan tindakan pada siklus II. Rencana tindakan yang akan dilaksanakan 3 kali pertemuan dengan materi yang lebih luas.

(1) menyusun silabus pembelajaran sesuai dengan kompetensi dasar mata pelajaran matematika tentang bilangan bulat;

(2) menyusun rencana pelaksanaan pembelajaran (RPP) matematika sesuai dengan kompetensi dasar dan silabus;

(3) menyusun tes awal untuk mengetahui hasil belajar siswa;

(4) menentukan lembar observasi/ pengamatan, dan;
(5) menyusun angket persepsi siswa untuk maple matematika.

b. Pelaksanaan: (1) peneliti melaksanakan proses belajar mengajar sesuai dengan rencana pembelajaran yang telah direncanakan sesuai hasil kesepakatan bersama dengan metode Jigsaw; dan (2) dalam pelaksanaan kegiatan pada tahapan ini adalah sebagai berikut: peneliti menjelaskan materi pembelajaran kepada anak tentang bilangan bulat tiga angka.

c. Observasi: (1) pengamatan dilakukan bersama-sama antara peneliti dengan kolaborator; (2) kegiatan yang dilakukan adalah observer mengamati pelaksanaan pembelajaran dari awal hingga akhir dengan menggunakan lembar pengamatan. Semua kegiatan ditujukan untuk mengenali, merekam dan mendokumentasikan setiap indikator dari proses dan hasil yang telah dicapai baik yang ditimbulkan oleh tindakan terencana maupun akibat sampingannya; dan (3) observasi ini dilakakukan untuk mengetahui kesesuaian pelaksanaan tindakan dengan rencana tindakan yang telah disusun sebelumnya, serta untuk mengetahui sebarapa jauh pelaksanaan tindakan yang sedang berlangsung dapat menghasilkan perubahan yang diharapkan yaitu meningkatkan hasil belajar matematika tentang bilangan bulat pada siswa kelas VI

d. Refleksi

Berdasarkan hasil analisis data dan kesimpulan, peneliti bersama dengan mitra/teman sejawat sebagai observer melakukan refleksi untuk mengadakan diskusi dan tinjauan masalah.Kemudian hasil evaluasi dan refleksi didiskusikan untuk menentukan keberhasilan pembelajaran.

\section{Pertemuan 2 (Selasa, 17 Oktober 2013)}

Waktu : 2 Jam pelajaran $=2 \times 35$ menit

a. Perencanaan:

Peneliti menyusun rencana untuk pelaksanaan tindakan pada pertemuan ke dua di siklus II. Rencana tindakan yang akan dilaksanakan 2 jam pelajaran (70 menit) dengan materi bilangan bulat.

b. Pelaksanaan: (1) peneliti melaksanakan proses belajar mengajar sesuai dengan rencana pembelajaran yang telah disusun dalam skenario pembelajaran dengan materi yang telah direncanakan sesuai hasil kesepakatan bersama. Dalam pelaksanaan kegiatan ini peneliti mengikuti petunjuk yang telah disusun dalam skenario pembelajaran dengan metode jigsaw; (2) kegiatan yang dilakukan pada tahapan ini adalah sebagai berikut: Peneliti menjelaskan materi pembelajaran 
kepada anak tentang bilangan bulat; (3) mengamati perilaku siswa selama kegiatan pembelajaran berlangsung dan mencatat semua kejadian yang ada selama proses pembelajaran.

c. Observasi: (1) pengamatan dilakukan bersamasama antara peneliti dengan kolaborator. Kegiatan ini dilakukan adalah observer mengamati pelaksanaan pembelajaran dari awal hingga akhir dengan menggunakan lembar pengamatan. Semua kegiatan ditujukan untuk mengenali, merekam dan mendokumentasikan setiap indikator dan proses dan hasil yang dicapai baik yang ditimbulkan oleh tindakan terencana maupun akibat sampingannya dan (2) observasi ini dilakukan untuk mengetahui kesesuaian pelaksanaan tindakan dengan rencana tindakan yang telah disusun sebelumnya, serta untuk mengetahui seberapa jauh pelaksanaan tindakan yang sedang berlangsung dapat menghasilkan perubahan yang diharapkan yaitu meningkatkan hasil belajar matematika tentang bilangan bulat pada siswa kelas VI.

d. Refleksi

Berdasarkan hasil analisis data dan kesimpulan, peneliti bersama dengan mitra/teman sejawat sebagai observer melakukan refleksi untuk mengadakan diskusi, evaluasi dan meninjau masalah.Kemudian hasil evaluasi dan refleksi didiskusikan untuk menentukan keberhasilan pembelajaran. Jika ternyata hasil yang dicapai belum maksimal, maka akan dilanjutkan pada pertemuan berikutnya.

Metode pengumpulan data dalam penelitian ini yaitu observasi adalah suatu tindakan pengamatan atau peninjauan secara langsung yang dilakukan dengan cermat. Tindakan observasi dilakukan guna memperoleh gambaran yang lebih jelas tentang kondisi yang ada pada objek penelitian, seperti penyampaian materi pembelajaran, respon murid, penggunaan media, dan sebagainya dengan menggunakan lembar observasi dan catatan lapangan. Instrumen penelitian tindakan kelas dalam penelitiani ini yaitu: (1) instrument tes, (2) lembar observasi, dan (3) angket persepsi siswa.

Teknik pengumpulan data yang digunakan dalam penelitian tindakan kelas ini adalah melalui tes dan lembar observasi.Tes diberikan untuk mengetahui kemampuan awal yang dimiliki siswa sebelum guru melaksanakan pembelajaran. Lembar observasi digunakan untuk mengamati jalannya proses pembelajaran yang menggunakan model cooperative learning tipe jigsaw untuk meningkatkan hasil belajar matematika siswa.

Alat pengumpulan data yang digunakan pada penelitian tindakan kelas ini adalah tes, lembar observasi dang angket. Data yang dikumpulkan pada setiap kegiatan observasi pada pelaksanaan penelitian tindakan kelas ini dianalisis secara deskriptif dengan menggunakan teknik persentasi untuk melihat kecenderungan yang terjadi dalam kegiatan pembelajaran.Melalui persentase yang dicapai dapat diketahui keberhasilan pelaksanaan penelitian tindakan kelas.

Hasil belajar matematika dikatakan tuntas jika siswa memperoleh nilai sama dengan atau lebih dari nilai KKM yaitu 65 dan dikatakan tidak tuntas jika nilai siswa kurang dari KKM yaitu 65. Model pembelajaran cooperative learning tipe jigsaw dikatakan telah berhasil bila rata-rata persentasi aktivitas siswa sama atau lebih dari $80 \%$, dan dikatakan tidak berhasil jika rata-rata aktivitas siswa kurang dari $80 \%$.

\section{HASIL DAN PEMBAHASAN}

\section{A. Data Awal Penelitian}

Sebelum peneliti melakukan tindakan kelas, peneliti bersama kolaborator melakukan Jigsaw kepada peserta didik yang akan diteliti untuk menyusun perencanaan tindakan, Jigsaw ini dilakukan pada minggu pertama Oktober 2013. Peneliti bersama kolaborator mencatat kemampuan anak pada lembar observasi dan mencatat skor yang diperoleh anak sebelum diberikan tindakan kelas. Rata-rata Jigsaw pada pra-tindakan mencapai $50,86 \%$ masih berada dibawah standar. Berdasarkan hal tersebut, maka perlu diadakan tindakan yang terdiri atas 2 siklus untuk meningkatkan hasil belajar matematika siswa kelas VII tentang bilangan bulat.

Sebelum melakukan tindakan, peneliti memberikan angket tentang persepsi siswa terhadap mata pelajaran matematika di kelas VI dengan tujuan untuk mengetahui sejauh mana siswa menyukai atau menyenangi mata pelajaran matematika. Hasil rekapitulasi angket juga menunjukkan bahwa kegiatan tindakan kelas belum mencapai keberhasilan sebagaimana tampak pada tabel 1 .

Tabel 1. Rekapitulasi Hasil Angket Persepsi Siswa Terhadap Mata Pelajaran Matematika

\begin{tabular}{|c|l|c|c|c|c|}
\hline \multirow{2}{*}{ NO } & \multicolumn{2}{|c|}{ PERTANYAAN } & \multicolumn{2}{|c|}{ YA } & \multicolumn{2}{c|}{ TIDAK } \\
\cline { 3 - 6 } & & Jml & $\%$ & Jml & (\%) \\
\hline 1 & $\begin{array}{l}\text { Apakah kamu senang dengan } \\
\text { pelajaran matematika? }\end{array}$ & 10 & 26,31 & 28 & 73,69 \\
\hline 2 & $\begin{array}{l}\text { Apakah kamu merasa puas } \\
\text { dengan penjelasan guru? }\end{array}$ & 14 & 36,48 & 24 & 63,52 \\
\hline 3 & $\begin{array}{l}\text { Apakah hasil ulanganmu pela- } \\
\text { jaran matematika sudah baik? }\end{array}$ & 15 & 39,47 & 23 & 60,53 \\
\hline
\end{tabular}




\begin{tabular}{|c|l|c|c|c|c|}
\hline \multirow{2}{*}{ NO } & \multicolumn{2}{|c|}{ PERTANYAAN } & \multicolumn{2}{|c|}{ YA } & \multicolumn{2}{c|}{ TIDAK } \\
\cline { 3 - 6 } & & Jml & $\%$ & Jml & (\%) \\
\hline 4 & $\begin{array}{l}\text { Apakah kamu dapat menjawab } \\
\text { soal yang diberikan guru? }\end{array}$ & 12 & 31,57 & 26 & 68,43 \\
\hline 5 & $\begin{array}{l}\text { Apakah kamu mengerjakan } \\
\text { semua tugas yg diberikan guru? }\end{array}$ & 9 & 23,68 & 20 & 76,32 \\
\hline
\end{tabular}

Dari hasil angket tersebut dapat dijelaskan bahwa siswa yang senang matematika hanya 13 orang dari 38 siswa, siswa puas dengan penjelasan guru sebanyak 14 siswa, siswa yang hasil ulangannya baik sebanyak 15 siswa, siswa yang dapat menjawab soal dari guru sebanyak 12 orang dan siswa yang mengerjakan tugas dengan baik sebanyak 9 orang.

Dari data dan diagram tersebut dapat di jelaskan bahwa secara keseluruhan persepsi terhadap mata pelajaran matematika memang masih rendah. Maka perlu diadakan tindakan untuk mengubah dan memperbaiki persepsi siswa dan hasil belajar agar lebih baik.

\section{B. Hasil Penelitian Siklus I}

Melihat hasil dari observasi pra-tindakan, maka peneliti mulai melakukan tindakan siklus I. Pelaksanaan tindakan siklus I pada minggu pertama bulan Oktober 2013. Siklus I dilakukan selama 3 kali pertemuan, pertemuan pertama dan kedua untuk kegiatan pembelajaran dan pertemuan ketiga diberikan evaluasi untuk mengetahui keberhasilan model pembelajaran atau metode yang digunakan yaitu metode Jigsaw dan mengetahui hasil belajar siswa.

\section{Siklus I ( $3 \times$ pertemuan)}

a.Membuat rencana pelaksanaan pembelajaran untuk pelaksanaan tindakan pada siklus I. rencana tindakan yang akan dilaksanakan adalah memberikan penjelasan tentang bilangan bulat.

b. Mempersiapkan alat dan media yang akan digunakan.

c. Membuat lembar observasi dan menyiapkan buku catatan lapangan yang akan dijadikan acuan penentu keberhasilan pembelajaran.

d. Memberikan lembar pengamatan dan observasi kepada teman sejawat.

e. Menentukan dan menetapkan waktu pelaksanaan. Kegiatan yang dilakukan adalah :

\section{1) Pertemuan Pertama}

Pertemuan pertama dilakukan pada hari Selasa, 01 Oktober 2013.Kegiatan diawali dengan berdoa, apersepsi dan pemberian motivasi oleh guru. kemudian guru membagikan angket persepsi terhadap pelajaran matematika selama 5 menit.Selanjutnya guru membagi kelompok. Siswa di bagi menjadi beberapa kelompok dan satu kelompok ahli.

Kemudian guru mengadakan percakapan pagi yang disertai dengan pembahasan tentang tema.Pada tahap ini guru melaksanakan kegiatan yang telah direncanakan yaitu memberikan penjelasan tentang bilangan bulat dengan menggunakan metode jigsaw. Guru menjelaskan dan sesekali guru memberikan pertanyaan kepada siswa.

2) Pertemuan Kedua

Pertemuan kedua dilakukan pada hari Kamis, 03 Oktober 2013.Kegiatan diawali dengan berdoa, apersepsi dan pemberian motivasi oleh guru. Kemudian berbagi cerita tentang materi yang telah mereka dapatkan pada pertemuan pertama.Pada tahap ini guru melaksanakan kegiatan yang telah direncanakan. Guru menjelaskan tentang bilangan bulat sesekali memberikan pertanyaan kepada siswa.

Setelah itu guru mengajak siswa untuk melakukan kegiatan Tanya jawab sesuai dengan materi pelajaran.demikian juga selama kegiatan pembelajaran guru bersama kolaborator mengamati. Hasil pengamatan aktivitas siswa dalam pembelajaran pada pertemuan pertama dan kedua dapat di lihat pada tabel 2 berikut.

Tabel 2. Hasil Pengamatan Aktivitas Siswa Dalam Pembelajaran Pada Siklus I

\begin{tabular}{|c|l|c|c|}
\hline No & KOMPONEN YANG DIAMATI & JML & $\%$ \\
\hline 1 & Bertanya kepada guru & 15 & 39,47 \\
\hline 2 & Menjawab pertanyaan guru & 8 & 21,05 \\
\hline 3 & Memberikan pendapat & 12 & 31,57 \\
\hline 4 & Aktif dalam diskusi & 28 & 73,88 \\
\hline 5 & Ketepatan mengumpulkan tugas & 30 & 78,94 \\
\hline
\end{tabular}

Berdasarkan data tersebut, ternyata pada siklus I menunjukkan bahwa siswa cukup aktif dan selalu memberikan respon positif dalam setiap pembelajaran yang di kembangkan dalam penelitian ini, akan tetapi belum maksimal. Dilihat dari ketepatan mengumpulkan tugas pekerjaan rumah diberikan oleh guru menunjukkan bahwa minat, motivasi belajar dan keinginan untuk belajar siswa sangat tinggi. Ketepatan mengumpulkan tugas ditentukan melalui ketepatan waktu, yaitu pada saat masuk kelas sebelum pembelajaran dimulai tugas harus sudah dikumpulkan.Sementara untuk aspek siswa bertanya kepada guru dan menjawab pertanyaan dari guru masih kurang.Siswa belum terbiasa untuk bertanya ataupun malu saat menjawab pertanyaan yang diajukan oleh guru. 


\section{Hasil Penelitian Siklus II}

Siklus II di lakukan selama 3 kali pertemuan yaitu Kamis 10 Oktober 2013.Selasa 17 Oktober 2013 dan kamis 19 Oktober 2013.Melihat hasil dari tindakan siklus I yang masih belum maksimal hasilnya, maka peneliti mulai melakukan tindakan siklus II dengan memperbaiki kekurangan yang ada pada siklus I. Pelaksanaan tindakan siklus II pada minggu kedua Oktober 2013.

Tahap perencanaan ini dilaksanakan dengan langkah-langkah membuat rencana kegiatan pembelajaran untuk melaksanakan tindakan pada siklus II, memberikan pertanyaan atau masalah kepada siswa untuk di cari jawaban atas permasalahan yang diberikan, membuat lembar jigsaw dan menyiapkan buku catatan untuk menulis hasil catatan lapangan yang akan dijadikan alat tes di setiap akhir pertemuan siklus, memberikan lembar pengamatan dan observasi kepada teman sejawat dan memperbaiki kekurangan yang ada pada siklus I, antara lain sebagai berikut: (1) menganjurkan siswa aktif dalam proses belajar mengajar (PBM); (2) memberikan uraian dengan jelas tentang materi pelajaran dan tugas yang diberikan; (3) memotivasi anak dalam menyelesaikan tugas.

Kegiatan yang dilakukan adalah:

1. Pertemuan Pertama

Pada pertemuan ini guru membahas tentang bilangan bulat. Diawali dengan kegiatan berdoa, salam, apersepsi dan pemberian motivasi oleh guru. Guru memberikan tugas kepada siswa, kemudian siswa mencari jawaban sendiri. Setelah itu guru mengajak siswa untuk melakukan kegiatan tanya jawab dan diskusi dengan menjawab setiap pertanyaan dari guru.

2. Pertemuan Kedua

Pada pertemuan ini guru membahas tentang bilangan bulat negative disertai dengan pemberian contoh. Kegiatan diawali dengan berdoa, salam, apersepsi dan pemberian motivasi oleh guru. Guru melaksanakan kegiatan yang telah direncanakan bertanyakepada siswa tentang bilangan yang di berikan tugas kepada siswa. Guru mengajukan pertanyaan kepada siswa tentang bilangan bulat negatif.

Selama kegiatan pembelajaran guru bersama kolaborator mengamati dan mencatat aktivitas siswa dalam pembelajaran sampai akhir pelajaran. Kemudian memberikan umpan balik kepada siswa dan memotivasi siswa. Hasil pengamatan aktivitas siswa dalam pembelajaran pada pertemuan pertama dan kedua dapat di lihat pada tabel 3.
Tabel 3. Hasil Pengamatan Aktivitas Siswa Dalam Pembelajaran Siklus II

\begin{tabular}{|c|l|c|c|}
\hline No & KOMPONEN YANG DIAMATI & JML & $\%$ \\
\hline 1 & Bertanya kepada guru & 21 & 55,26 \\
\hline 2 & Menjawab pertanyaan guru & 16 & 42,10 \\
\hline 3 & Memberikan pendapat & 23 & 60,52 \\
\hline 4 & Aktif dalam diskusi & 32 & 84,21 \\
\hline 5 & Ketepatan mengumpulkan tugas & 34 & 89,47 \\
\hline
\end{tabular}

Berdasarkan data pada tabel 3, ternyata pada siklus II menunjukkan bahwa siswa sudah lebih aktif dan selalu memberikan respon positif dalam setiap pembelajaran yang dikembangkan dalam penelitian ini dan lebih baik dari siklus I. dilihat dari ketepatan mengumpulkan tugas pekerjaan rumah diberikan oleh guru menunjukkan bahwa minat, motivasi belajar dan keinginan untuk belajar siswa sangat tinggi .Sementara untukaspek siswa bertanya kepada guru dan menjawab pertanyaan dari guru masih kurang. Siswa belum terbiasa untuk bertanya ataupun malu saat menjawab pertanyaan yang di ajukan oleh guru.

3. Pertemuan Ketiga

Pada pertemuan ketiga pelaksanaan penelitian hanya melakukan penilaian hasil belajar selama siklus II, dengan diadakan tes untuk mengetahui hasil belajar siswa pada siklus II, apakah ada peningkatan di bandingkan dengan siklus I. Berikut ini merupakan hasil tes yang diberikan pada siklus II dan nilai minimal sebesar 5.00. Data tersebut dapat dilihat pada tabel 4 .

Tabel 4. Nilai Hasil Belajar Siswa Pada Siklus I

\begin{tabular}{|c|c|c|c|c|}
\hline Rata-rata & Daya Serap & Nilai Min & Nilai Maks & Ketuntasan \\
\hline 66,97 & 66,97 & 50,00 & 85,00 & 68,42 \\
\hline
\end{tabular}

Dari tabel tersebut dapat dijelaskan bahwa nilai rata-rata hasil belajar siswa dan daya serap kelas sebesar $66,97 \%$, nilai tersebut sudah melampaui batas nilai KKM yaitu 65, akan tetapi ketuntasan belajarnya masih rendah hanya $68,42 \%$ belum mencapai sesuai yang di harapkan yaitu $85 \%$. Jadi penelitian dapat dilanjutkan pada siklus II agar hasil penelitian lebih baik sesuai yang di harapkan.

Dari hasil tes tersebut bahwa rata-rata hasil belajar sebesar 70,53 dengan daya serap sebesar $70,53 \%$. Dengan ketuntasan belajar sebesar $86,84 \%$. Sementara untuk nilai maksimal sebesar 90 dan nilai minimal sebesar 55,00. Data tersebut dapat dilihat pada tabel 5 . 
Tabel 5. Nilai Hasil Belajar Siswa Pada Siklus II

\begin{tabular}{|c|c|c|c|c|}
\hline Rata-rata & Daya Serap & Nilai Min & Nilai Maks & Ketuntasan \\
\hline 70,53 & 70,53 & 55,00 & 90,00 & 86,84 \\
\hline
\end{tabular}

Dari tabel 5 dapat dijelaskan bahwa nilai ratarata hasil belajar siswa dan daya serap kelas sebesar 70,53. Nilai tersebut sudah melampaui batas nilai KKM yaitu 65, demikian juga dengan ketuntasan belajarnya sudah melampaui indikator yang diharapkan 86,84\%. Jadi penelitian tidak perlu dilanjutkan pada siklus berikutnya.

\section{Pembahasan}

\section{Aktivitas Siswa}

Analisis terhadap masing-masing aktivitas siswa dalam pembelajaran siklus I dengan menggunakan metode Jigsaw menunjukkan bahwa aktivitas siswa bertanya kepada guru, menjawab pertanyaan, dan aktif memberikan pendapat belum menunjukkan hasil yang memuaskan, karena masih dibawah nilai Kriteria Ketuntasan Minimal, yaitu 65, dari 2 kali pertemuan pembelajaran di kelas. Hal ini antara lain disebabkan siswa masih terlihat canggung dalam pembelajaran yang bervariasi (diskusi, presentasi dan latihan), dimana banyak siswa yang masih terlihat ragu-ragu untuk melaksanakan diskusi dan mempresentasikan hasilnya.

Pada siklus II, kondisi tersebut tampak mengalami perbaikan mengalami peningkatan yang cukup emmuaskan jika dibandingkan dengan kondisinya pada siklus I, hamper semua komponen atau aspek aktivitas siswa yang diamati guru bersama observer meningkat seperti ditampilkan pada tabel 6 .

Tabel 6. Rekapitulasi Aktivitas Belajar Siswa Siklus I dan Siklus II

\begin{tabular}{|c|l|c|c|c|c|}
\hline \multirow{2}{*}{ NO } & \multicolumn{2}{|c|}{ PERTANYAAN } & \multicolumn{2}{c|}{ SIKLUS I } & \multicolumn{2}{c|}{ SIKLUS II } \\
\cline { 3 - 7 } & & Jml & $\%$ & Jml & $(\%)$ \\
\hline 1 & Bertanya kepada guru & 15 & 39,47 & 21 & 55,26 \\
\hline 2 & Menjawab pertanyaan guru & 8 & 21,05 & 16 & 42,10 \\
\hline 3 & Memberikan pendapat & 12 & 31,57 & 23 & 60,52 \\
\hline 4 & Aktif dalam diskusi & 28 & 73,68 & 32 & 84,21 \\
\hline 5 & $\begin{array}{l}\text { Ketepatan mengumpulkan } \\
\text { tugas }\end{array}$ & 30 & 78,94 & 34 & 89,47 \\
\hline
\end{tabular}

Dari tabel 6, komponen siswa bertanya kepada guru mengalami kenaikan sebesar 15,79\% dan 39,47\% pada siklus I menjadi 55,26\% pada siklus II. Komponen siswa mampu menjawab pertanyaan guru naik $21,05 \%$ dari $21,05 \%$ pada siklus I menjadi $42,10 \%$ pada siklus II. Komponen siswa memberikan pendapat meningkat sebesar $28,95 \%$ dari $31,57 \%$ pada siklus I menjadi
$60,52 \%$ pada siklus II. Komponen siswa aktif dalam diskusi Tanya jawab dengan guru meningkat sebesar $10,53 \%$ dari $73,68 \%$ pada siklus I menjadi $84,21 \%$ pada siklus II dan komponen siswa yang tepat dalam mengumpulkan tugas meningkat sebesar 10,53\% dari $78,94 \%$ pada siklus I menjadi $89,47 \%$ pada siklus II.

\section{Hasil Belajar}

Hasil belajar siswa dalam penelitian ini dengan menggunakan metode Jigsaw yang diperoleh siswa selama siklus I dan siklus II dapat dibuat rekapitulasi perbandingannya pada tabel 7 .

Tabel 7. Perbandingan Hasil Belajar Siswa Pada Siklus I dan Siklus II

\begin{tabular}{|c|l|c|c|}
\hline \multirow{2}{*}{ NO } & \multicolumn{2}{|c|}{ KRITERIA } & \multicolumn{2}{c|}{ SIKLUS } \\
\cline { 3 - 4 } & & I & II \\
\hline 1 & Rata-rata nilai & 66,97 & 70,53 \\
\hline 2 & Daya Serap & 66,97 & 70,53 \\
\hline 3 & KKM & 65 & 65 \\
\hline 4 & Ketuntasan & 68,42 & 86,84 \\
\hline
\end{tabular}

Dari tabel 7 tersebut rata-rata nilai hasil belajar siswa pada siklus I ke siklus II mengalami kenaikan 3,56 point, yaitu dari 65,97 pada siklus I menjadi 70,53 pada siklus II. Sementara untuk ketuntasan belajar mengalami kenaikan sebesar 18,42\% dari siklus I sebesar $68,42 \%$ menjadi $86,84 \%$ pada siklus II. Kenaikan nilai siswa sangat dipengaruhi oleh penguasaan materi, dan penguasaan materi akan terjadi jika pembelajaran di kelas berhasil. Siswa sudah terbiasa dan mulai mendapat kecocokan dalam berkelompok.Dengan menggunakan metode Jigsaw meningkatkan hasil belajar yang lebih baik. Dari data aktivitas siswa dan hasil belajar yang di peroleh pada siklus I dan siklus II menunjukkan bahwa metode Jigsaw dalam pembelajaran ini ternyata dapat menciptakan suasana belajar yang bergairah dan memotivasi siswa serta memancing kreatifitas siswa.

\section{PENUTUP}

\section{Kesimpulan}

Berdasarkan hasil observasi dan hasil tes yang dilaksanakan mulai prasiklus/pratindakan sampai dengan siklus II, maka dapat disimpulkan bahwa hasil belajar matematika pokok bahasan penjumlahan dan pengurangan bilangan tiga angka dapat ditingkatkan melalui metode cooperative learning tipe jigsaw siswa kelas VI SDN Duri Pulo 01 Pagi, Kecamatan Gambir - Jakarta pusat semester ganjil Tahun Pelajaran 2013/2014 dengan prolehan data sebagai berikut: 
Hasil tes yang dicapai pada siklus I menunjukkan bahwa masih banyak siswa yang hasil belajar Matematikanya rendah, akan tetapi hal tersebut berubah pada siklus II. Rata-rata nilai hasil belajar siswa pada siklus I ke siklus II mengalami kenaikan 3,56 poin, yaitu dari 66,97 pada siklus I menjadi 70,53 pada siklus II. Demikian juga dengan daya serap siswa mengalami kenaikan sebesar 3,56\% yaitu dari $66,97 \%$ pada siklus I menjadi $70,53 \%$ pada siklus II. Sementara untuk ketuntasan belajar mengalami kenaikan sebesar $18,42 \%$ dari siklus I sebesar $68,42 \%$ menjadi $86,84 \%$ pada siklus II.

Selain hasil belajar, aktivitas siswa pada saat pembelajaran mengalami peningkatan.Aktivitas siswa yang paling menonjol adalah kemampuan siswa mengemukakan -pendapat saat diskusi dan Tanya jawab dengan guru.Siswa juga terlihat lebih aktif dan berperan serta menciptakan situasi belajar yang menyenangkan.

\section{Saran}

Berdasarkan kesimpulan diatas, maka pada kesempatan ini peneliti memberikan beberapa saran sebagai berikut: (1) kepada siswa agar selalu meningkatkan kwalitas belajar sehingga hasil belajar matematika akan meningkat; (2) guru agar membuat perencanaan pembelajaran lebih efektif sehingga dapat meningkatkan hasil belajar siswa. Selain itu guru harus mencari inovasi dengan menerapkan metode yang tepat dalam pembelajaran, sehingga siswa bergairah dalam belajar; dan (3) sarana dan prasarana pendukung pembelajaran baik media pembelajaran maupun alat peraga hendaknya diupayakan agar pembelajaran menjadi lebih efektif.

\section{DAFTAR PUSTAKA}

Azwar, S. (2001). Ilmu pendidikan. Jakarta: Rineka Cipta Bloom, B. S. ed.et al. (1956).Taxonomy of education objectives: Handbook 1, cognitive domain. New York: David Mckay

Dendasurono. (1988). Metodologi pengajaran. Jakarta: IKIP Jakarta

Djamrah, S.B. \& Zain, A. (2002). Strategi belajar mengajar. Jakarta: Rineka Cipta

Moeliono, Anton M. (1995). Kamus besar bahasa Indonesia. Jakarta: Balai Pustaka

Mulyasa, E. (2007). Menjadi guru profesional. Jakarta: Remaja Rosdakarya

Purwanto N. (1992). Psikologi pendidikan. Bandung: PT. Remaja Rosda Karya.

Ratnawati, M. (2010). "Motif berprestasi dan prestasi". Jurnal Anima Vol XI No. 42

Ruseffendi. (1984). Dasar-dasar matematika modern dan komputer untuk guru. Bandung: Tarsito

Sabri, A. (2007). Strategi belajar mengajar. Ciputat: Quantum Teaching

Sia,T. (2000). "Hubungan antara IQ, EQ dan QA dengan prestasi studi pada siswa SMU". Jurnal Anima Vol 17 no. 1

Suhardjono, S. (2011). Strategi menyusun penelitian tindakan kelas. Yogyakarta: Andi Offset

Surakhmad, W. (1979). Pembangunan instruksional. Bandung: Tarsito

Suryabrata, S. (1998). Psikologi pendidikan. Jakarta: PT Raja Grafindo Persada

Winkel, W.S. (1997). Psikologi pendidikan dan evaluasi belajar. Jakarta: Gramedia

Wuryani, S.E. (2006). Psikologi pendidikan. Jakarta: Grasindo 